\title{
Survivorship care plans in cancer: a systematic review of care plan outcomes
}

\author{
M E Brennan*,1,2,3, J F Gormally ${ }^{3}$, P Butow ${ }^{4}$, F M Boyle ${ }^{2,3}$ and A J Spillane ${ }^{1,2,3,5}$ \\ ${ }^{1}$ Breast and Surgical Oncology at The Poche Centre, North Sydney, NSW, Australia; ${ }^{2}$ Northern Clinical School, Sydney Medical \\ School, The University of Sydney, Sydney, NSW, Australia; ${ }^{3}$ The Mater Hospital, North Sydney, NSW, Australia; ${ }^{4}$ Psycho-oncology \\ Co-operative Research Group (PoCoG), The University of Sydney, Sydney, NSW, Australia and ${ }^{5}$ Royal North Shore Hospital, \\ St Leonards, NSW, Australia
}

Background: Eight years after the Institute of Medicine recommended survivorship care plans (SCPs) for all cancer survivors, this study systematically reviewed the evidence for their use.

Methods: Studies evaluating outcomes after implementation of SCPs for cancer survivors were identified by searching databases (MEDLINE, EMBASE and Cochrane). Data were extracted and summarised.

Results: Ten prospective studies (2286 survivors) met inclusion criteria (5 randomised controlled trials (RCTs)). Study populations included survivors of breast, gynaecological, colorectal and childhood cancer. Several models of SCP were evaluated (paper based/on-line, oncologist/nurse/primary-care physician-delivered and different templates). No significant effect of SCPs was found on survivor distress, satisfaction with care, cancer-care coordination or oncological outcomes in RCTs. Breast cancer survivors with SCPs were better able to correctly identify the clinician responsible for their follow-up care. One study suggested a positive impact on reducing unmet needs. Levels of survivor satisfaction with, and self-reported understanding of, their SCP were very high. Feasibility was raised by health professionals as a significant barrier, as SCPs took $1-4 \mathrm{~h}$ of their time to develop.

Conclusions: Emerging evidence shows very few measurable benefits of SCPs. Survivors reported high levels of satisfaction with SCPs. Resource issues were identified as a significant barrier to implementation.

The many long-term challenges, unmet needs and gaps in care facing cancer survivors were highlighted in the Institute of Medicine's 2006 landmark report From Cancer Patient to Cancer Survivor: Lost in Transition (Hewitt et al, 2006). Issues for survivors include late effects of cancer treatment, lifelong emotional effects and tumour recurrence. The report also outlined service provision issues such as poor coordination of care, lack of communication between health practitioners and patient uncertainty about who is responsible for providing long-term care (Hewitt et al, 2006). The 'survivorship care plan' (SCP), an individualised treatment summary and plan for ongoing care, was proposed as a solution to many of these issues. Many cancer treatment guidelines around the world now suggest or recommend that every cancer patient be provided with an SCP at the completion of treatment, and many suggest that this be delivered in a dedicated appointment with a trained and competent health professional (Hewitt et al, 2006; Khatcheressian et al, 2006; National Breast and Ovarian Cancer Centre (NBOCC), 2010; Khatcheressian et al, 2013; American Society of Clinical Oncology \& Cancer.Net, 2013). There is evidence that cancer survivors and their primary-care physicians are receptive to the concept of SCPs and there has also been strong support for them from consumer groups (Hewitt et al, 2007; Kantsiper et al, 2009; Brennan et al, 2011; Livestrong Foundation Livestrong Care Plan (http://www.livestrongcareplan.org/); Marbach and Griffle, 2011; Smith et al, 2011).

Enthusiasm for SCPs has been tempered by the realisation that their implementation is resource-intensive (Jefford et al, 2011; Spain et al, 2012; Brothers et al, 2013). In the context of looming shortages in the oncology professional workforce, evidence of their 
benefit is crucial to justify recommendations for the routine and universal implementation of SCPs (Erikson et al, 2007; Medical Oncology Group of Australia, 2009).

This study systematically reviewed the evidence evaluating outcomes following development and implementation of SCPs in cancer survivorship.

\section{MATERIALS AND METHODS}

Studies for this evidence review were identified by searching the literature to the end of June 2013. MEDLINE and EMBASE databases and the Cochrane Database of Systematic Reviews were searched using the keywords 'cancer' and 'care plan', 'survivorship care plan' and 'follow-up care'. Reference lists of background articles and eligible studies were searched to identify additional studies.

Eligibility criteria were as follows: original studies evaluating a standardised written care plan (defined as a structured multifaceted plan for long-term or follow-up care) in cancer survivors (defined as patients having completed treatment for early cancer with curative intent) and reporting quality of life, satisfaction with care or care plan and/or oncological outcomes. Follow-up care was defined as long-term medical care after treatment for early cancer. Studies evaluating care plans that included only one aspect of care (e.g., those evaluating a targeted dietary, psychological or exercise intervention) were not eligible, as the aim was to review the evidence relating to multifaceted care plans. Review articles and those focusing on patients with metastatic cancer were not eligible for inclusion. The screening process is summarised in Figure 1 (PRISMA flowchart) (Liberati et al, 2009).

Titles, abstracts and then full-text publications were assessed against the pre-determined eligibility criteria for study inclusion. Unclear cases were discussed and resolved with a second investigator. Data were extracted by two independent reviewers and were summarised in evidence tables. Discrepancies were resolved with review by a third reviewer. Extracted data included information about patient population (cancer type and demographic data), the type of care plan evaluated, outcomes evaluated and results of the study. Each included study was assessed for study quality using the 'QualSyst' tool, a standard checklist of 14 items (Kmet et al, 2004). This tool was developed for systematic reviews and used in previous reviews (Kmet et al, 2004; St Jacques et al, 2008; Agarwal et al, 2013; Laidsaar-Powell et al, 2013; Wassenaar et al, 2014). Each eligible study was given an overall quality score (Kmet et al, 2004), independently by two investigators. Items contributing to the quality score included study design, randomisation, outcome measures and analytic methods (Kmet et al, 2004). Mean quality scores were reported for each study.

\section{RESULTS}

Search results and description of eligible studies. The initial search identified 2262 studies. Of these, seven abstracts met eligibility criteria and all of these remained eligible following review of full-text articles (Oeffinger et al, 2010; Grunfeld et al, 2011; Blaauwbroek et al, 2012; Spain et al, 2012; Blinder et al, 2013; Brothers et al, 2013; Hershman et al, 2013). Five further studies were identified from reference lists of eligible studies and referenced papers, and all of these were also eligible for inclusion in the final analysis (Grunfeld et al, 1996, 1999a, b, 2006; Jefford et al, 2011). Three of the 12 eligible studies reported different outcomes of the same randomised trial; hence, these were considered as one study for the purposes of this review (Grunfeld et al, 1996, 1999a,b). The findings of 10 studies are

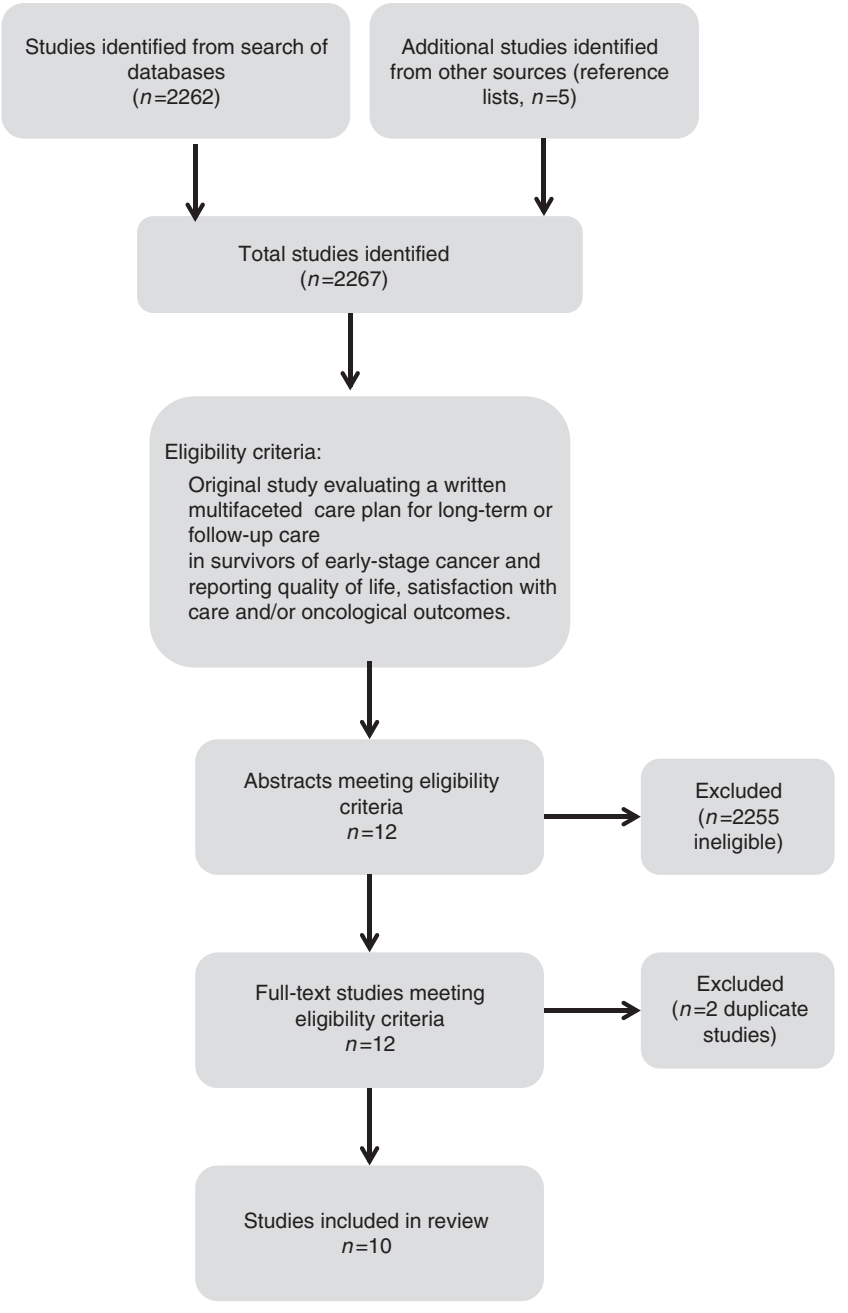

Figure 1. Prisma Flowchart (Liberati et al, 2009).

therefore presented (Grunfeld et al, 1996, 2006, 2011; Oeffinger et al, 2010; Jefford et al, 2011; Blaauwbroek et al, 2012; Spain et al, 2012; Blinder et al, 2013; Brothers et al, 2013; Hershman et al, 2013). These included 2286 trial participants (mean 254 participants (median 126) in each trial).

All studies were prospective studies of SCPs in cancer survivors (Table 1) (Grunfeld et al, 1996, 2006, 2011; Oeffinger et al, 2010; Jefford et al, 2011; Blaauwbroek et al, 2012; Spain et al, 2012; Blinder et al, 2013; Brothers et al, 2013). All studies used predominantly quantitative methodology (Grunfeld et al, 1996, 2006, 2011; Oeffinger et al, 2010; Jefford et al, 2011; Blaauwbroek et al, 2012; Spain et al, 2012; Blinder et al, 2013; Brothers et al, 2013; Hershman et al, 2013). Five studies evaluated SCPs in survivors of breast cancer (Grunfeld et al, 1996, 2006, 2011; Blinder et al, 2013; Hershman et al, 2013), three in adult survivors of childhood cancers (Oeffinger et al, 2010; Blaauwbroek et al, 2012; Spain et al, 2012) and one each in survivors of gynaecological cancer (Brothers et al, 2013) and colorectal cancer (Jefford et al, 2011). There were five randomised controlled trials (RCTs) (Grunfeld et al, 1996, 2006, 2011; Brothers et al, 2013; Hershman et al, 2013), four in breast cancer (Grunfeld et al, 1996, 2006, 2011; Hershman et al, 2013) and one in gynaecological cancer (Brothers et al, 2013). The remaining studies were nonrandomised observational studies (Oeffinger et al, 2010; Jefford et al, 2011; Blaauwbroek et al, 2012; Spain et al, 2012; Blinder et al, 2013). Four studies were conducted in the United States (Spain et al, 2012; Blinder et al, 2013; Brothers et al, 2013; Hershman et al, 2013), two in Canada (Grunfeld et al, 2006, 2011), one across the 
Table 1. Studies reporting outcomes following implementation of SCPs in cancer (grouped by study design and ordered by year of publication)

\begin{tabular}{|c|c|c|c|c|c|c|c|c|}
\hline $\begin{array}{l}\text { Author, } \\
\text { year } \\
\text { (country) }\end{array}$ & $\begin{array}{l}\text { Tumour } \\
\text { type }\end{array}$ & Population & $N$ & $\begin{array}{c}\text { Age } \\
\text { (years, } \\
\text { mean or } \\
\text { median) }\end{array}$ & Description of trial & Description of SCP & $\begin{array}{l}\text { Development/ } \\
\text { introduction of SCP }\end{array}$ & $\begin{array}{l}\text { Quality } \\
\text { score, } \\
\text { mean }^{a}\end{array}$ \\
\hline \multicolumn{9}{|c|}{ Randomised controlled trials (SCP or no SCP) } \\
\hline $\begin{array}{l}\text { Hershman } \\
\text { et al, } 2013 \\
\text { (USA) }\end{array}$ & $\mathrm{BC}$ & $\begin{array}{l}<6 \text { Weeks post } \\
\text { treatment }\end{array}$ & 126 & 54 & $\begin{array}{l}\text { Randomised (standard } \\
\text { follow-up or standard plus } \\
\text { SCP) } \\
\text { Questionnaires }(0,3,6 \\
\text { months) } \\
\text { SCP template not } \\
\text { described }\end{array}$ & $\begin{array}{l}\text { Paper: } \\
\text { 1. Treatment summary } \\
\text { 2. Follow-up care plan } \\
\text { 3. Late-effects information }\end{array}$ & $\begin{array}{l}\text { Developed and } \\
\text { introduced by nurse } \\
\text { practitioner and } \\
\text { nutritionist in specialised } \\
\text { 1-h consultation }\end{array}$ & $\begin{array}{c}0.98(0.96, \\
1.00)\end{array}$ \\
\hline $\begin{array}{l}\text { Brothers et al, } \\
2013 \text { (USA) }\end{array}$ & $\begin{array}{l}\text { Gynaecologic } \\
\text { cancer }\end{array}$ & $\begin{array}{l}<1 \text { Year post } \\
\text { treatment }\end{array}$ & 121 & 60 & $\begin{array}{l}\text { Randomised to standard } \\
\text { follow-up consultation by } \\
\text { oncologist or standard } \\
\text { consultation plus SCP. } \\
\text { Questionnaire after SCP } \\
\text { consultation } \\
\text { LiveStrong SCP template }\end{array}$ & $\begin{array}{l}\text { Paper SCP: } \\
\text { 1. Treatment summary } \\
\text { 2. Follow-up care plan } \\
\text { 3. Information about } \\
\text { survivorship/follow-up }\end{array}$ & $\begin{array}{l}\text { Developed by research } \\
\text { assistant } \\
\text { Introduced by oncologist } \\
\text { (routine consultation) }\end{array}$ & $\begin{array}{c}0.88(0.81 \\
0.96)\end{array}$ \\
\hline $\begin{array}{l}\text { Grunfeld } \\
\text { et al, } 2011 \\
\text { (Canada) }\end{array}$ & $\mathrm{BC}$ & $\begin{array}{l}\geqslant 3 \text { Months post } \\
\text { treatment }\end{array}$ & 408 & 62 & $\begin{array}{l}\text { All discharged to PCP } \\
\text { Randomised (standard } \\
\text { oncologist discharge } \\
\text { consultation or standard } \\
\text { plus SCP with nurse } \\
\text { education) } \\
\text { Own SCP template } \\
\text { developed } \\
\text { Questionnaire (12 months) }\end{array}$ & $\begin{array}{l}\text { Paper: SCP plus nurse- } \\
\text { delivered educational } \\
\text { session: } \\
\text { 1. Personal treatment } \\
\text { summary } \\
\text { 2. Copy of national follow- } \\
\text { up guidelines (patient } \\
\text { edition) } \\
\text { 3. Summary table for } \\
\text { follow-up } \\
\text { 4. Supportive care } \\
\text { resource kit }\end{array}$ & $\begin{array}{l}\text { Developed by oncology } \\
\text { nurse/team } \\
\text { Introduced by nurse in } \\
\text { with survivor }\end{array}$ & $\begin{array}{c}0.94(0.88, \\
1.00)\end{array}$ \\
\hline $\begin{array}{l}\text { Grunfeld } \\
\text { et al, } 2006 \\
\text { (Canada) }\end{array}$ & $\mathrm{BC}$ & $\begin{array}{l}\text { 9-15 Months } \\
\text { post diagnosis }\end{array}$ & 968 & 61 & $\begin{array}{l}\text { Randomised (standard } \\
\text { follow up at hospital (no } \\
\text { SCP) or PCP (with SCP) } \\
\text { Own SCP template } \\
\text { Questionnaire }\end{array}$ & $\begin{array}{l}\text { Paper SCP: } \\
\text { 1. Treatment summary } \\
\text { 2. Recommendations for } \\
\text { follow-up care } \\
\text { 3. Indications for } \\
\text { investigation/indications for } \\
\text { referral back to cancer } \\
\text { centre }\end{array}$ & $\begin{array}{l}\text { Developed by oncology } \\
\text { team } \\
\text { Mailed to primary-care } \\
\text { physician }\end{array}$ & $\begin{array}{c}1.00(1.00, \\
1.00)\end{array}$ \\
\hline $\begin{array}{l}\text { Grunfeld } \\
\text { et al, } 1996 \\
\text { (UK) }\end{array}$ & $\mathrm{BC}$ & $\begin{array}{l}\text { Survivors } \\
\text { ( } 2 \text { hospitals) }\end{array}$ & 296 & $59 / 62$ & $\begin{array}{l}\text { Randomised (standard } \\
\text { follow-up hospital (no SCP) } \\
\text { or PCP (with SCP) } \\
\text { Own SCP template } \\
\text { Questionnaire }\end{array}$ & $\begin{array}{l}\text { Paper SCP: } \\
\text { 1. Treatment summary } \\
\text { 2. Individual follow-up } \\
\text { recommendations } \\
\text { 3. Handbook on follow-up } \\
\text { care }\end{array}$ & $\begin{array}{l}\text { Developed by oncology } \\
\text { team } \\
\text { Mailed to primary-care } \\
\text { physician }\end{array}$ & $\begin{array}{c}1.00(1.00, \\
1.00)\end{array}$ \\
\hline \multicolumn{9}{|c|}{ Non-randomised prospective studies (whole cohort received SCP) } \\
\hline $\begin{array}{l}\text { Blinder et al, } \\
2013 \text { (USA) }\end{array}$ & $\mathrm{BC}$ & $\begin{array}{l}\text { Newly diagnosed } \\
\text { All oncologists } \\
\text { ASCO BCR Pilot } \\
\text { Program } \\
\text { Multicentre }\end{array}$ & 174 & 58 & $\begin{array}{l}\text { Evaluation of 'treatment } \\
\text { plan and summary } \\
\text { document' } \\
\text { Introduction of survivorship } \\
\text { documents at start of } \\
\text { chemo (if having chemo) or } \\
\text { end of treatment } \\
\text { ASCO TPS template } \\
\text { Telephone survey after } \\
\text { documents received }\end{array}$ & $\begin{array}{l}\text { Paper SCP: } \\
\text { 1. Treatment plan (before } \\
\text { chemo) } \\
\text { 2. Summary document } \\
\text { (treatment summary/ } \\
\text { survivorship } \\
\text { recommendations) } \\
\text { (given separately or } \\
\text { together depending on } \\
\text { treatment) }\end{array}$ & $\begin{array}{l}\text { Developed by oncologist } \\
\text { Introduced by oncologist } \\
\text { in standard treatment or } \\
\text { follow-up consultation }\end{array}$ & $\begin{array}{c}0.78(0.62 \\
0.94)\end{array}$ \\
\hline $\begin{array}{l}\text { Spain et al, } \\
2012 \text { (USA) }\end{array}$ & $\begin{array}{l}\text { Paediatric } \\
\text { cancer (adult } \\
\text { survivors) }\end{array}$ & $\begin{array}{l}\text { Adult long-term } \\
\text { follow-up clinic }\end{array}$ & 111 & 30 & $\begin{array}{l}\text { SCP introduced at routine } \\
\text { consultation } \\
\text { Own template (MSKCC) } \\
\text { Telephone survey (1-6 } \\
\text { weeks after SCP) }\end{array}$ & $\begin{array}{l}\text { Paper SCP: } \\
\text { 1. Treatment summary } \\
\text { 2. Follow-up care plan }\end{array}$ & $\begin{array}{l}\text { Developed by medical } \\
\text { team } \\
\text { Introduced by oncologist } \\
\text { in standard consultation }\end{array}$ & $\begin{array}{c}0.82(0.69, \\
0.95)\end{array}$ \\
\hline $\begin{array}{l}\text { Blaauwbroek } \\
\text { et al, } 2012 \\
\text { (Netherlands) }\end{array}$ & $\begin{array}{l}\text { Paediatric } \\
\text { cancer (adult } \\
\text { survivors) }\end{array}$ & $\begin{array}{l}\text { Survivors off- } \\
\text { treatment } \geqslant 5 \\
\text { years, not in a } \\
\text { follow-up } \\
\text { programme }\end{array}$ & $\begin{array}{l}73 \\
\text { Survivors; } \\
72 \text { family } \\
\text { doctors }\end{array}$ & 38 & $\begin{array}{l}\text { Evaluation on-line SCP for } \\
\text { survivors and PCPs } \\
\text { Survivors made } \\
\text { appointment with PCP to } \\
\text { have care plan } \\
\text { implemented }\end{array}$ & $\begin{array}{l}\text { Written web-based plan } \\
\text { (on-line and printed book); } \\
\text { accessible on line to } \\
\text { survivor and PCP) } \\
\text { Components: } \\
\text { 1. Treatment summary }\end{array}$ & $\begin{array}{l}\text { Developed by specialist } \\
\text { oncologist } \\
\text { Self-administered website } \\
\text { viewed by survivor } \\
\text { Directed to survivorship } \\
\text { consultation with PCP for }\end{array}$ & $\begin{array}{c}0.72(0.67, \\
0.77)\end{array}$ \\
\hline
\end{tabular}




\section{Table 1. (Continued)}

\begin{tabular}{|c|c|c|c|c|c|c|c|c|}
\hline $\begin{array}{l}\text { Author, } \\
\text { year } \\
\text { (country) }\end{array}$ & $\begin{array}{l}\text { Tumour } \\
\text { type }\end{array}$ & Population & $N$ & $\begin{array}{c}\text { Age } \\
\text { (years, } \\
\text { mean or } \\
\text { median) }\end{array}$ & Description of trial & Description of SCP & $\begin{array}{l}\text { Development/ } \\
\text { introduction of SCP }\end{array}$ & $\begin{array}{l}\text { Quality } \\
\text { score, } \\
\text { mean }^{a}\end{array}$ \\
\hline & & & & & $\begin{array}{l}\text { Own template/website } \\
\text { developed } \\
\text { Questionnaire for survivor } \\
\text { and PCP }\end{array}$ & $\begin{array}{l}\text { 2. Follow-up care plan/late } \\
\text { effects monitoring plan }\end{array}$ & $\begin{array}{l}\text { implementation of } \\
\text { follow-up plan }\end{array}$ & \\
\hline $\begin{array}{l}\text { Jefford et al, } \\
2011 \\
\text { (Australia) }\end{array}$ & CRC & $\begin{array}{l}<12 \text { Months } \\
\text { after treatment }\end{array}$ & 10 & 55 & $\begin{array}{l}\text { SCP/survivorship package } \\
\text { introduced by nurse in } \\
\text { educational consultation } \\
\text { IOM template } \\
\text { Questionnaires and } \\
\text { interview }\end{array}$ & $\begin{array}{l}\text { Paper: SCP (part of } \\
\text { survivorship package) } \\
\text { Survivorship package } \\
\text { components } \\
\text { 1. Survivorship information } \\
\text { (DVD, information booklet, } \\
\text { question prompt list) } \\
\text { 2. SCP, individualised } \\
\text { treatment summary and } \\
\text { follow-up care plan } \\
\text { including supportive care } \\
\text { information } \\
\text { 3. Nurse-led end-of- } \\
\text { treatment consultation } \\
\text { 4. } 3 \text { Follow-up telephone } \\
\text { calls }\end{array}$ & $\begin{array}{l}\text { Developed by oncology } \\
\text { nurse/medical team } \\
\text { Introduced by nurse at a } \\
\text { specialised end-of- } \\
\text { treatment consultation }\end{array}$ & $\begin{array}{c}0.61(0.58 \\
0.64)\end{array}$ \\
\hline $\begin{array}{l}\text { Oeffinger } \\
\text { et al, } 2010 \\
\text { (USA/ } \\
\text { Canada) }\end{array}$ & $\begin{array}{l}\text { Paediatric } \\
\text { Hodgkin } \\
\text { lymphoma } \\
\text { (adult } \\
\text { survivors) }\end{array}$ & $\begin{array}{l}\geqslant 5 \text {-Year } \\
\text { survivors } \\
\text { Elevated risk BC/ } \\
\text { cardiomyopathy } \\
\text { (multi-institu- } \\
\text { tional database) }\end{array}$ & 72 & 37 & $\begin{array}{l}\text { Evaluation of mailed SCP; } \\
\text { aim encourage late effects } \\
\text { screening } \\
\text { (echocardiography/ } \\
\text { mammography) via PCP } \\
\text { Own SCP template } \\
\text { Questionnaire (baseline) } \\
\text { interview (6 months) }\end{array}$ & $\begin{array}{l}\text { Paper format mailed SCP: } \\
\text { 1. Treatment summary } \\
\text { 2. Summary late effects } \\
\text { 3. Screening } \\
\text { recommendations } \\
\text { Plus survivorship website }\end{array}$ & Not reported & $\begin{array}{c}0.76(0.77 \\
0.75)\end{array}$ \\
\hline
\end{tabular}

United States and Canada (Oeffinger et al, 2010), one in the United Kingdom (Grunfeld et al, 1996), one in the Netherlands (Blaauwbroek et al, 2012) and one in Australia (Jefford et al, 2011). Heterogeneity was noted in the point in the survivorship trajectory that recruitment occurred. Although one study recruited survivors at diagnosis or during chemotherapy (Blinder et al, 2013), there were others that included survivors of breast cancer, who had completed treatment several years before entering the study (Grunfeld et al, 1996, 2006, 2011).

The quality scores for the studies reflected the suboptimal methodology of many studies (overall mean score $=0.85$, mean for RCTs $=0.96$, mean for non-RCTs $=0.74$, Table 1 ). Maximum possible score was 1.0.

\section{SCPs - models evaluated}

SCP format and content. Of the 10 studies, 9 evaluated paperbased SCPs (Grunfeld et al, 1996, 2006, 2011; Oeffinger et al, 2010; Jefford et al, 2011; Spain et al, 2012; Blinder et al, 2013; Brothers et al, 2013; Hershman et al, 2013) and one evaluated a web-based document (Blaauwbroek et al, 2012) (Table 1).

All studies evaluated SCPs that consisted of at least two components: a treatment summary and a plan for long-term follow-up care. Nine of the 10 SCPs were accompanied by other survivorship resources such as booklets, DVDs or websites that contained information about late effects of treatment, supportive care, lifestyle/general health information or copies of follow-up care guidelines (Grunfeld et al, 1996, 2006, 2011; Oeffinger et al, 2010; Jefford et al, 2011; Blaauwbroek et al, 2012; Blinder et al, 2013; Brothers et al, 2013; Hershman et al, 2013).

Most of the SCPs were developed primarily as a resource for cancer survivors (Oeffinger et al, 2010; Grunfeld et al, 2011; Jefford et al, 2011; Blaauwbroek et al, 2012; Spain et al, 2012; Blinder et al,
2013; Brothers et al, 2013; Hershman et al, 2013). Copies were frequently sent to the primary-care physician, oncologist or other health professionals involved in care, and survivors were encouraged to share their SCP with family and practitioners who may not have been sent a copy.

In two studies, the SCP was developed specifically as a resource for primary-care physicians to facilitate discharge from cancer centrebased follow-up to general practice (Grunfeld et al, 1996, 2006). Although these 'discharge plans' may not traditionally be considered to be SCPs, they met the definition of multifaceted plans for longterm care; hence, they were included in the review. These two studies were conducted before the term 'survivorship care plan' was in common use and they are considered to be landmark studies of novel models of follow-up care after cancer treatment (Grunfeld et al, 1996, 2006). It should be noted, however, that the effect of the SCPs in these studies is confounded by the fact that survivors with an SCP were followed up in primary care and those without an SCP were followed up in a cancer centre, as the trials were designed to evaluate the practitioner delivering the care rather than the care plan itself (Grunfeld et al, 1996, 2006).

Most SCPs for survivors of adult cancers were developed at the end of treatment. The exception was a study that combined a treatment plan developed at the beginning of chemotherapy with an SCP developed separately at the end of treatment (Blinder et al, 2013). In the studies of survivors of childhood cancers, one focused on survivors over the age of 18 years, who were already attending a follow-up clinic (Spain et al, 2012). The other two included only adult survivors who were treated more than 5 years ago and who were not necessarily attending for follow-up care (Oeffinger et al, 2010; Blaauwbroek et al, 2012).

SCP development and introduction. Several different models of SCP delivery were evaluated. All SCPs were developed by the 
treatment team. Some were delivered to the patient by an oncologist during a normal follow-up visit (Spain et al, 2012; Blinder et al, 2013; Brothers et al, 2013) and others were delivered during a specialised educational consultation with a specialist nurse (Grunfeld et al, 2011; Jefford et al, 2011; Hershman et al, 2013). Three were sent by mail, either to the patient (Oeffinger et al, 2010) or primary-care physician (Grunfeld et al, 1996, 2006), and one was a web-based SCP with log-in details sent to patient and primary-care physician (Blaauwbroek et al, 2012).

All SCPs were developed using standardised templates. One study used the American Society of Clinical Oncology SCP template (American Society of Clinical Oncology \& Cancer.Net, 2013; Blinder et al, 2013), one the LiveStrong SCP template (Brothers et al, 2013 and Livestrong Foundation Livestrong Care Plan (http://www.livestrongcareplan.org/)), one adapted the Institute of Medicine template (Hewitt et al, 2006; Jefford et al, 2011) and the remaining studies developed their own template for use in the study and/or for routine institutional use (Grunfeld et al, 1996, 2006, 2011; Oeffinger et al, 2010; Blaauwbroek et al, 2012; Spain et al, 2012; Hershman et al, 2013).

\section{Outcomes}

Randomised controlled trials. There have been five RCTs of SCPs (Grunfeld et al, 1996, 2006, 2011; Brothers et al, 2013; Hershman et al, 2013) (Table 2). The two earliest studies evaluating breast cancer follow-up care in primary care with a standardised follow-up protocol (considered as an SCP) showed no difference in the primary outcomes of cancer recurrence and anxiety/depression, and they concluded that follow-up in primary care with the SCP (rather than in a hospital clinic) is safe (Grunfeld et al, 1996, 2006). One of these studies (Grunfeld et al, 1996) evaluated satisfaction and economic outcomes (published separately) (Grunfeld et al, 1999a, b) and found that patient satisfaction with health care was higher in the primary care/SCP group, and that although more diagnostic tests were ordered in the primary care group, the cost of tests overall was no different and the cost of follow-up to the patient (in the United Kingdom) was less in the primary care/SCP group compared with the hospital group (Grunfeld et al, 1999a, b).

A later study by the same investigators evaluated a more formal, individualised SCP, randomising breast cancer survivors receiving follow-up in primary care to receive an SCP or standard (primary) care without the SCP. They found that there was no difference in the primary outcomes of various aspects of health-related quality of life but there was a statistically significant difference in the number of women who correctly identified their primary-care physician as the clinician responsible for their follow-up care, with more women doing so in the SCP group (Grunfeld et al, 2011).

A further RCT, also in breast cancer survivors, also found no overall difference in the primary outcomes (Hershman et al, 2013). There was a transient decrease in cancer-related anxiety in women in the intervention group but this was not sustained. The study also looked for differences between Hispanic and non-Hispanic survivors, and there was no significant difference between racial groups (Hershman et al, 2013).

The remaining RCT was conducted in gynaecological cancer survivors (Brothers et al, 2013). It evaluated response to the SCP and perception of care in the consultation wherein the SCP was delivered. It was found that survivors overall were very satisfied with the care and consultation, and that there was no difference between the two groups in any of the outcomes measured (Brothers et al, 2013).

The remaining five (non-RCT) studies were prospective studies in which the whole cohort received an SCP (Oeffinger et al, 2010; Jefford et al, 2011; Blaauwbroek et al, 2012; Spain et al, 2012; Blinder et al, 2013).
Results for individual outcomes are reported below, across all studies.

Health-related quality of life. The effect of SCPs on health-related quality of life (HRQOL) has been assessed in five studies (Grunfeld et al, 1996, 2006, 2011; Jefford et al, 2011; Hershman et al, 2013). Four of these were the RCTs in breast cancer survivors, described in the previous section (Grunfeld et al, 1996, 2006, 2011; Hershman et al, 2013). No difference was found when measuring HRQOL using SF-36 (Grunfeld et al, 1996, 2006, 2011) and FACTB (Hershman et al, 2013). The other study measuring HRQOL in detail was a small $(n=10)$ non-randomised pilot study of colorectal cancer survivors receiving an SCP as part of a survivorship package (Jefford et al, 2011). In this study there was similar HRQOL before and after implementation, measured by the EORTC QLQ-C30 and QLQ-CR29 (Jefford et al, 2011). However, there were fewer unmet needs after implementation of the package using the Cancer Survivors Unmet Needs scale (Jefford et al, 2011). The investigators are currently conducting a randomised trial in this Australian population.

Distress/cancer-related distress. The RCTs that included the evaluation of distress in breast cancer survivors found no difference between the SCP and no-SCP groups (Grunfeld et al, 1996, 2006, 2011; Hershman et al, 2013)measured by the Hospital Anxiety and Depression Scale (Grunfeld et al, 1996, 2006) and the Impact of Events Scale (Grunfeld et al, 2011). In one of these RCTs, there was a significantly lower level of health worry (measured by the Assessment of Survivor Concerns questionnaire) in the SCP group at 3 months but this was not seen at the 6-month measurement (Hershman et al, 2013). There was also no difference in Profile of Mood States score before and after receiving an SCP by mail in a group of adult survivors of childhood cancer considered to be at substantially elevated risk of breast cancer or cardiomyopathy due to previous cancer treatment (Oeffinger et al, 2010).

A study in a cohort receiving SCPs found that distress may be lower in survivors with an SCP; $72 \%$ of breast cancer patients surveyed after receiving an SCP said it gave them greater peace of mind (measured by a Likert scale developed for the study) (Blinder et al, 2013).

However, other studies found that distress may be higher in survivors with an SCP (Jefford et al, 2011; Blaauwbroek et al, 2012; Spain et al, 2012). In one study, the proportion of colorectal cancer patients experiencing distress increased from $30 \%$ at baseline as measured by the Brief Symptom Inventory (BSI-18) to $37 \%$ at the second assessment point (Jefford et al, 2011). This study also showed a slight increase in distress at follow-up, measured by the Distress Thermometer (Jefford et al, 2011). In another study where all participants had an SCP, 17\% reported worrying 'frequently' or 'almost constantly' about their health (assessed by one item in the Memorial Symptom Assessment Scale) (Spain et al, 2012). Thirtyone per cent of childhood cancer survivors surveyed 2 weeks after receiving an SCP at a routine follow-up visit said that reading the treatment summary and care plan or at least one of its individual sections had caused them distress (Spain et al, 2012), and in a study of childhood cancer survivors $20 \%$ of those given an on-line SCP said it triggered negative memories (Blaauwbroek et al, 2012) and $20 \%$ of the related primary care physicians surveyed were concerned that the SCP may trigger negative memories in their patients (Blaauwbroek et al, 2012). These studies had a much lower quality score than the RCTs that showed no increase in distress (Table 1).

Survivor satisfaction with care plan. All studies evaluating the overall satisfaction of survivors with their SCP showed very high levels of satisfaction. Colorectal cancer survivors expressed high levels of 
Table 2. Outcomes following implementation of SCPs in cancer (grouped by study design and ordered by year of publication)

\begin{tabular}{|c|c|c|c|c|c|}
\hline $\begin{array}{l}\text { Author } \\
\text { (year) }\end{array}$ & $\begin{array}{l}\text { Description of } \\
\text { trial and SCP }\end{array}$ & Outcomes & Measures & Results & Conclusions \\
\hline \multicolumn{6}{|c|}{ Randomised controlled trials (SCP or no SCP) } \\
\hline $\begin{array}{l}\text { Hershman } \\
\text { et al, } 2013\end{array}$ & $\begin{array}{l}\text { BC; standard follow- } \\
\text { up or standard plus } \\
\text { SCP; } n=126\end{array}$ & $\begin{array}{l}\text { 1.Treatment satisfaction } \\
\text { 2.Impact of cancer } \\
\text { 3. Health and cancer worry } \\
\text { 4.HRQOL } \\
\text { 5.Depression } \\
\text { 6.Cancer symptoms } \\
\text { 7.Ethnicity (Hispanic/non- } \\
\text { Hispanic) }\end{array}$ & $\begin{array}{l}\text { FACIT-TS-PS } \\
\text { IOC } \\
\text { ASC } \\
\text { FACT-B } \\
\text { CES-D } \\
\text { Memorial Symptoms } \\
\text { Assessment Scale } \\
\text { All measures }\end{array}$ & $\begin{array}{l}\text { No difference } \\
\text { No difference } \\
\text { Less worry in intervention } \\
\text { group at } 3 \text { months; did not } \\
\text { persist at 6-month evaluation } \\
\text { No difference } \\
\text { No difference } \\
\text { No difference } \\
\text { No significant persistent } \\
\text { difference }\end{array}$ & $\begin{array}{l}\text { No short-term benefit of SCP } \\
\text { (6 months) } \\
\text { Decrease in cancer-related } \\
\text { worry (did not persist) }\end{array}$ \\
\hline $\begin{array}{l}\text { Brothers } \\
\text { et al, } 2013\end{array}$ & $\begin{array}{l}\text { Gynaecologic cancer; } \\
\text { standard consultation } \\
\text { or standard plus } \\
\text { LiveStrong SCP; } \\
n=121\end{array}$ & $\begin{array}{l}\text { 1.Satisfaction (administrative } \\
\text { services) } \\
\text { 2.Satisfaction (clinical services) } \\
\text { 3.Satisfaction (educational } \\
\text { services) } \\
\text { 4. Satisfaction (helpfulness of } \\
\text { written materials) }\end{array}$ & \begin{tabular}{|l|} 
Administrative services \\
scale \\
Clinical services scale \\
Educational services scale \\
\\
Helpfulness of Written \\
Materials scale
\end{tabular} & $\begin{array}{l}\text { No difference } \\
\text { No difference } \\
\text { No difference } \\
\text { No difference }\end{array}$ & $\begin{array}{l}\text { No effect of SCP on rating of } \\
\text { health services }\end{array}$ \\
\hline $\begin{array}{l}\text { Grunfeld } \\
\text { et al, } 2011\end{array}$ & $\begin{array}{l}\text { BC; usual follow-up } \\
\text { (PCP) or usual plus } \\
\text { SCP; } n=408\end{array}$ & $\begin{array}{l}\text { 1. Cancer-related distress } \\
\text { 2.General distress } \\
\text { 3.HRQOL } \\
\text { 4.Patient satisfaction } \\
\text { 5.Continuity/coordination of care } \\
\text { 6. Health service } \\
\text { (a) Identify clinician responsible } \\
\text { for care } \\
\text { (b) Number of visits to } \\
\text { oncologist }\end{array}$ & $\begin{array}{l}\text { Impact of events scale } \\
\text { POMS } \\
\text { SF 36, PCS and MCS } \\
\text { MOS-PSO } \\
\text { CCCQ } \\
\text { New measure developed } \\
\text { Number of visits }\end{array}$ & $\begin{array}{l}\text { No difference } \\
\text { No difference } \\
\text { No difference } \\
\text { No difference } \\
\text { No difference } \\
\\
\text { SCP group better identified } \\
\text { PCP as person responsible for } \\
\text { follow-up }(P=0.005) \\
\text { No difference }\end{array}$ & $\begin{array}{l}\text { SCPs do not improve PROs. } \\
\text { Patients with SCPs are } \\
\text { significantly more aware of } \\
\text { doctor responsible for } \\
\text { follow-up care }\end{array}$ \\
\hline $\begin{array}{l}\text { Grunfeld } \\
\text { et al, } 2006\end{array}$ & $\begin{array}{l}\text { BC; usual follow-up } \\
\text { (hospital clinic, no } \\
\text { SCP or PCP with } \\
\text { SCP); } n=968\end{array}$ & $\begin{array}{l}\text { 1.Recurrence } \\
\text { 2.Serious clinical event } \\
\text { 3.Death } \\
\text { 4.HRQOL } \\
\text { 5.Distress }\end{array}$ & $\begin{array}{l}\text { Recurrence rate } \\
\text { Event rate } \\
\text { Death rate } \\
\text { SF-36 } \\
\text { HADS }\end{array}$ & $\begin{array}{l}\text { No difference } \\
\text { No difference } \\
\text { No difference } \\
\text { No difference } \\
\text { No difference }\end{array}$ & $\begin{array}{l}\text { Serious events rare; equal } \\
\text { frequency in both groups } \\
\text { BC patients can safely be } \\
\text { followed-up by PCP }\end{array}$ \\
\hline $\begin{array}{l}\text { Grunfeld } \\
\text { et al, } 1996\end{array}$ & $\begin{array}{l}\text { BC; randomised to } \\
\text { usual follow-up at } \\
\text { hospital clinic (no } \\
\text { SCP) or follow-up with } \\
\text { PCP (with SCP); } \\
n=296\end{array}$ & $\begin{array}{l}\text { 1.Recurrence } \\
\text { 2.Time to diagnosis recurrence } \\
\text { 3.HRQOL } \\
\text { 4.Distress } \\
\text { 5.Economic evaluation } \\
\text { 6.Satisfaction with care }\end{array}$ & $\begin{array}{l}\text { Recurrence rate } \\
\text { Time to recurrence } \\
\text { EORTC symptom scale } \\
\text { SF-36 } \\
\text { HADS } \\
\text { Cost calculation } \\
\text { UK College of Health }\end{array}$ & $\begin{array}{l}\text { No difference } \\
\text { No difference } \\
\text { No difference } \\
\text { No difference } \\
\text { No difference } \\
\text { PCP follow-up visits less costly } \\
\text { than hospital follow-up; cost of } \\
\text { diagnostic tests no diff } \\
\text { PCP follow-up higher level of } \\
\text { patient satisfaction than } \\
\text { hospital follow-up }\end{array}$ & $\begin{array}{l}\text { PCP follow-up no increase in } \\
\text { time to diagnosis. } \\
\text { No difference in anxiety, or } \\
\text { deterioration in HRQOL } \\
\text { PCP less costly to patient; no } \\
\text { difference in cost of tests } \\
\text { PCP follow-up higher } \\
\text { satisfaction }\end{array}$ \\
\hline \multicolumn{6}{|c|}{ Non-randomised prospective studies (whole cohort received SCP) } \\
\hline $\begin{array}{l}\text { Blinder } \\
\text { et al, } 2013\end{array}$ & $\begin{array}{l}\text { BC; ASCO template } \\
\text { treatment plan and } \\
\text { summary document } \\
\text { given at consultation; } \\
n=174\end{array}$ & $\begin{array}{l}\text { 1. Perception about } \\
\text { communication with and } \\
\text { between physicians } \\
\text { 2. Perception about peace of } \\
\text { mind } \\
\text { 3. Perception about using } \\
\text { documents in future } \\
\text { 4. Perceptions about support }\end{array}$ & $\begin{array}{l}\text { Likert scale } \\
\text { Likert scale } \\
\text { Likert scale }\end{array}$ & \begin{tabular}{|l|}
$44 \%$ Said helps \\
communication between \\
patient and doctor; $82 \%$ \\
between health professionals \\
$72 \%$ Greater peace of mind \\
$56 \%$ Likely to use again \\
$70 \%$ Right amount of support \\
from health professionals; $69 \%$ \\
right amount of information \\
about cancer and treatment \\
$96 \%$ Understood planned \\
treatment; $96 \%$ felt prepared \\
for what to expect from their \\
treatment
\end{tabular} & $\begin{array}{l}\text { Survivors react favourably } \\
\text { when treatment plans are } \\
\text { personalised and } \\
\text { implemented as part of their } \\
\text { oncologic care. }\end{array}$ \\
\hline
\end{tabular}




\section{Table 2. (Continued)}

\begin{tabular}{|c|c|c|c|c|c|}
\hline $\begin{array}{l}\text { Author } \\
\text { (year) }\end{array}$ & $\begin{array}{l}\text { Description of } \\
\text { trial and SCP }\end{array}$ & Outcomes & Measures & Results & Conclusions \\
\hline $\begin{array}{l}\text { Spain et al, } \\
2012\end{array}$ & $\begin{array}{l}\text { Paediatric cancer } \\
\text { (adult survivors); } \\
\text { SCP introduced in } \\
\text { consultation; } n=111\end{array}$ & $\begin{array}{l}\text { 2. Understanding of SCP } \\
\text { 3. Value of SCP } \\
\text { 4. Dissemination of document } \\
\text { 5. Concern raised by receiving } \\
\text { SCP } \\
\text { 6. Worry about health } \\
\text { 7. Preferences for format of SCP }\end{array}$ & $\begin{array}{l}\text { Single item } \\
\text { Likert scale } \\
\text { Single item } \\
\text { Single item } \\
\text { Memorial Symptom } \\
\text { Assessment Scale } \\
\text { Preferences for paper } \\
\text { form vs wallet card, } \\
\text { online, e-mail }\end{array}$ & $\begin{array}{l}95 \% \text { Reported understanding } \\
93 \% \text { Moderately or extremely } \\
\text { valuable } \\
44 \% \text { Shared with others in } \\
\text { personal circle } \\
14 \% \text { Caused concern; } 86 \% \text { not } \\
17 \% \text { Frequent or almost } \\
\text { constant worry about health } \\
95 \% \text { interest in an online or } \\
\text { wallet-card version of the } \\
\text { treatment summary and care } \\
\text { plan }\end{array}$ & $\begin{array}{l}\text { Survivors retain, understand, } \\
\text { and value the treatment } \\
\text { summary and care plan in a } \\
\text { real-world clinic setting } \\
\text { Receipt of SCP did not cause } \\
\text { worry or concern in majority }\end{array}$ \\
\hline $\begin{array}{l}\text { Blaauw- } \\
\text { broek et al, } \\
2012\end{array}$ & $\begin{array}{l}\text { Paediatric cancer } \\
\text { (adult survivors); } \\
\text { web-based SCP for } \\
\text { survivor and PCP; } \\
n=73\end{array}$ & $\begin{array}{l}\text { 1. User friendliness (website) } \\
\text { 2. Satisfaction (SCP information) } \\
\text { 3. Negative memories triggered? } \\
\text { 4. Confidence in PCP }\end{array}$ & $\begin{array}{l}\text { Survey } \\
\text { Survey } \\
\text { Survey }\end{array}$ & $\begin{array}{l}\text { 95\% Survivors/97\% PCPs said } \\
\text { user friendly } \\
\text { 89\% Survivors } / 100 \% \text { PCP said } \\
\text { info is sufficient } \\
20 \% \text { Survivors negative } \\
\text { memories } \\
82 \% \text { Survivors } / 93 \% \text { PCPs } \\
\text { confident }\end{array}$ & $\begin{array}{l}\text { The availability of a web- } \\
\text { based personalised SCP } \\
\text { facilitates follow-up care in } \\
\text { shared-care model (late } \\
\text { effect outpatient clinic and } \\
\text { PCP) } \\
\text { SCP appreciated by } \\
\text { survivors }\end{array}$ \\
\hline $\begin{array}{l}\text { Jefford } \\
\text { et al, } 2011\end{array}$ & $\begin{array}{l}\text { CRC; nurse-delivered } \\
\text { survivorship package } \\
\text { with SCP; } n=10\end{array}$ & $\begin{array}{l}\text { 1. Unmet needs } \\
\text { 2. Distress } \\
\text { 3. HRQOL } \\
\text { 4. Satisfaction } \\
\text { 5. Feasibility }\end{array}$ & $\begin{array}{l}\text { CASUN scale } \\
\text { BSI-18 } \\
\text { EORTC QOL } \\
\text { questionnaire QLQ-C30/ } \\
\text { QLQ-CR29 } \\
\text { Survey developed for } \\
\text { study } \\
\text { Survey developed for } \\
\text { study }\end{array}$ & $\begin{array}{l}7 \text { Unmet needs at baseline, } \\
4 \text { at follow-up } \\
30 \% \text { Distress (baseline); } \\
37 \% \text { (follow-up) } \\
\text { Mean } 71 \text { (baseline), } 69 \\
\text { (follow-up) } \\
\text { High level of survivor } \\
\text { satisfaction } \\
\text { Feasible but resource intensive }\end{array}$ & $\begin{array}{l}\text { Feasibility confirmed } \\
\text { Acceptability confirmed } \\
\text { Participants valued all } \\
\text { intervention components } \\
\text { Resource intensive for health } \\
\text { professionals }\end{array}$ \\
\hline $\begin{array}{l}\text { Oeffinger } \\
\text { et al, } 2010\end{array}$ & $\begin{array}{l}\text { Paediatric Hodgkin } \\
\text { lymphoma } \\
\text { (adult survivors); } \\
\text { paper-based SCP } \\
\text { mailed to random } \\
\text { sample from multi- } \\
\text { institutional database; } \\
n=72\end{array}$ & $\begin{array}{l}\text { 1. Use of SCP } \\
\text { 2. Screening Practices }\end{array}$ & Survey & $\begin{array}{l}78 \% \text { Remembered receiving } \\
\text { SCP; half had shared plan } \\
\text { with PCP } \\
41 \% \text { Women had } \\
\text { mammogram within } \\
6 \text { months; } 20 \% \text { had } \\
\text { recommended } \\
\text { echocardiogram; additional } \\
1 / 3 \text { planned to have } \\
\text { recommended testing in the } \\
\text { next } 6 \text { months } \\
\text { Only } 19 \% \text { of PCPs approached } \\
\text { by survivors agreed to } \\
\text { participate in survey }\end{array}$ & $\begin{array}{l}\text { Feasibility demonstrated } \\
\text { Increase screening rates; } \\
\text { SCP favorably received. }\end{array}$ \\
\hline \multicolumn{6}{|c|}{ 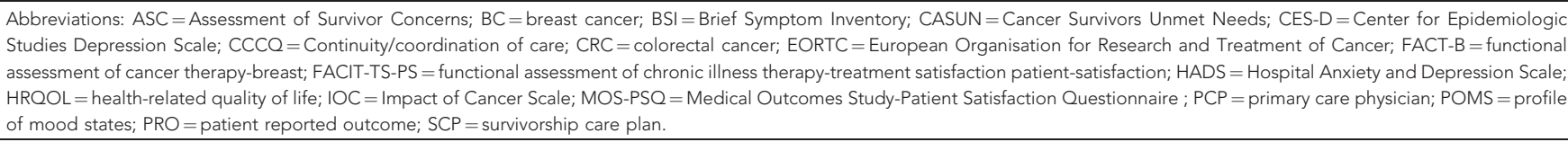 } \\
\hline
\end{tabular}

satisfaction in interviews after receiving an SCP in a nurse-led consultation; it was used as part of a survivorship package (including DVD and face-to-face educational session and follow-up phone calls) and participants valued all components of the intervention (Jefford et al, 2011). Positive feelings about the SCP were reported in a group of adult survivors of childhood cancer considered to be at substantially elevated risk of breast cancer or cardiomyopathy due to previous cancer treatment (Oeffinger et al, 2010).

In one of the RCTs, gynaecological cancer survivors were asked about the helpfulness of written materials that were given at cxonsultation (including in the intervention arm, the LiveStrong SCP) and there was no difference between the groups in rating of helpfulness (Brothers et al, 2013).

In the two studies that asked survivors to rate the amount of information contained in the SCP (Blaauwbroek et al, 2012; Spain et al, 2012), over $80 \%$ of survivors thought the amount of information was right (Blaauwbroek et al, 2012; Spain et al, 2012); in one of the studies, the primary-care physicians were also asked and 100\% were satisfied with the SCP (Blaauwbroek et al, 2012). 
Understanding of information in the SCP. Survivor understanding of SCP content was assessed in two studies (Spain et al, 2012; Blinder et al, 2013). In all of these, survivors were asked whether they understood the document, and all reported a high level of perceived understanding. This included self-reported understanding of SCP content in $98 \%$ (Blinder et al, 2013) of breast cancer survivors and in 95\% of childhood cancer survivors (Spain et al, 2012).

Patient satisfaction with medical care. In two RCTs in breast cancer survivors, higher levels of satisfaction with many aspects of the overall care and the consultation were seen in women having follow-up in primary care with an SCP compared with those having follow-up care without an SCP at a hospital clinic (Grunfeld et al, 1996, 2006). The follow-on study to this showed no difference in these outcomes in the SCP compared with the no-SCP group when all were followed-up in primary care (Grunfeld et al, 2011). The other RCTs (in gynaecological cancer and breast cancer survivors) also showed no difference in perception of care evaluated following a single consultation where the SCP or standard care was delivered (Brothers et al, 2013) or in satisfaction with care over a 6-month period (Hershman et al, 2013). Another study evaluating satisfaction with care found that $70 \%$ of breast cancer survivors (all receiving a SCP) surveyed after receiving the plan felt they got the right amount of general support from health professionals; $69 \%$ felt they received the right amount of information about cancer and treatment (Blinder et al, 2013).

Uptake of recommended screening. One study was designed primarily to assess whether an SCP received by mail would increase uptake of recommended screening for late effects in a group of adult survivors of childhood cancer considered to be at substantially elevated risk of breast cancer or cardiomyopathy due to previous cancer treatment (Oeffinger et al, 2010). In this study (where all participants received an SCP), $41 \%$ of women had a mammogram within 6 months of receiving the care plan; $20 \%$ of survivors had a recommended echocardiogram; and an additional one-third of the group planned to have testing in the next 6 months (Oeffinger et al, 2010). It is not clear whether this was an improvement on the screening rate in a similar population without an SCP. No long-term data were provided in any studies; thus, it is unknown whether this will translate to improved survival.

Feasibility. Feasibility and provider time factors were reported in five studies (Grunfeld et al, 1999b; Jefford et al, 2011; Spain et al, 2012; Brothers et al, 2013; Hershman et al, 2013).

In a pilot study of colorectal cancer survivors, SCP use was considered feasible but resource intensive; it was estimated that 1-1.5 h was required for an oncology nurse to complete SCPs and, in addition, staff with clinical experience had to verify the accuracy of the SCP (Jefford et al, 2011). In another study, an SCP developed for adult survivors of childhood cancer was estimated to take the medical team 1-4h to develop (Spain et al, 2012). In the RCT in gynaecological cancer survivors, it took a research assistant an average of $1.5 \mathrm{~h}$ (range 1-2) to prepare the SCP (Brothers et al, 2013). A further study commented that development of the SCP had a significant cost related to use of health resources but did not quantify this (Hershman et al, 2013).

\section{Other outcomes}

- Oncological outcomes: There was no difference in recurrence (Grunfeld et al, 1996, 2006) or serious clinical events (Grunfeld et al, 2006) in two RCTs of breast cancer survivors having follow-up with SCP implemented by primary-care physician vs survivors having follow-up in a hospital clinic without SCP (Grunfeld et al, 1996, 2006).

- Survivor perception of care coordination: There was no difference in an RCT of primary care follow-up with SCP or no SCP (measured by Continuity/coordination of care questionnaire (Grunfeld et al, 2011).

- Survivor perception of communication role of SCP: $94 \%$ of breast cancer survivors surveyed after receiving an SCP thought it would be useful for communication between patient and doctor; $82 \%$ thought it would improve communication between health professionals (measured by a Likert scale developed for the study) (Blinder et al, 2013).

- Sharing of SCP: In studies of adult survivors of childhood cancer, 44\% (Spain et al, 2012) and 50\% (Oeffinger et al, 2010) said they had shared their SCP with other people in their personal circle, and breast cancer survivors reported using the SCP to facilitate discussions with family members (Blinder et al, 2013).

None of the studies included in the review reports long-term outcomes following the implementation of an SCP. This includes an absence of data regarding quality of life/psychosocial outcomes, adherence to recommended screening regimens and long-term recurrence and survival data.

\section{DISCUSSION}

This systematic review identified 10 studies (5 of them were RCTs) that met inclusion criteria. Study populations included survivors of breast, gynaecological, colorectal and childhood cancer, and several different models of SCP were evaluated. Although levels of survivor satisfaction with SCPs were very high, no significant effect was found on survivor distress, satisfaction with care, cancer-care coordination or oncological outcomes in the RCTs. One study suggested a positive impact on reducing unmet needs (Jefford et al, 2011). Potential harm (increase in distress) was suggested in some non-randomised studies. Resource issues were identified as a significant barrier to implementation.

Two questions arose from the IOM report (Hewitt et al, 2006): (1) will treatment summaries and SCPs improve care for cancer survivors and (2) what is the ideal model for implementation of SCPs and their incorporation into routine practice?

In 2006 when the IOM recommended the development of a treatment summary and SCP for every cancer survivor (Hewitt et al, 2006), only two of the studies identified in this review (evaluating outcomes of models of survivorship care similar to that proposed by the report) had been published (Grunfeld et al, 1996, 2006). Since then, there have been many studies showing that survivors are very enthusiastic about the concept of an SCP (Hewitt et al, 2007; Kantsiper et al, 2009; Brennan et al, 2011; Marbach and Griffle, 2011; Smith et al, 2011); this is accompanied by cautious interest from many oncology health professionals (Hewitt et al, 2007; Brennan et al, 2010) and some concerns from other professionals (Hewitt et al, 2007; Kantsiper et al, 2009). Many models and methods of delivery have been proposed, and survivor and health provider preferences have been assessed (de Bock et al, 2004; Cox et al, 2006; Ganz and Hahn, 2008; Greenfield et al, 2009; Marbach and Griffle, 2011).

Research has progressed from exploring preferences to focusing on evaluating different models of survivorship care planning.

Despite this burgeoning interest, only 10 studies were identified for inclusion in the current review (Grunfeld et al, 1996, 2006, 2011; Oeffinger et al, 2010; Jefford et al, 2011; Blaauwbroek et al, 2012; Spain et al, 2012; Blinder et al, 2013; Brothers et al, 2013; Hershman et al, 2013). None of the five randomised studies identified found a significant or sustained benefit to quality of life, distress, quality of care/care coordination or oncological outcomes from the SCP. It is unclear from detailed evaluation of these studies whether the failure to detect benefits is due to these SCPs actually not being beneficial, or whether it is related to other factors. Some of these studies may fail to identify the most appropriate outcomes 
to evaluate, use of insensitive outcome measures, or fail to include or identify a subgroup of cancer survivors who may benefit from SCPs more than others. Using the example of breast cancer, it is possible that one outcome of an SCP may be better compliance with adjuvant endocrine therapy but this has not been measured. It is also possible, for example, that breast cancer survivors, a group that is overrepresented in the RCTs of SCPs, and a group that is already relatively well informed and well supported, may not be the survivors most likely to benefit from SCPs.

Many of the studies in the review asked survivors for feedback on the SCP they were given (Oeffinger et al, 2010; Jefford et al, 2011; Blaauwbroek et al, 2012; Spain et al, 2012; Brothers et al, 2013). The feedback was extremely positive, consistent with the previous background survivorship research showing great enthusiasm for SCPs from cancer survivors. In the studies in this review, survivors reported having a good understanding of the content of the SCP (Spain et al, 2012; Blinder et al, 2013), valuing and sharing the information with clinicians and family members. These studies suggest that despite having no measureable benefit in RCTs, SCPs appear to be highly valued by survivors. However, as patients and survivors are often very positive about elements of their care, these data are not sufficient to warrant routine use of SCPs.

Several studies have raised the possibility that there may be some harm from SCPs; they may increase distress in some survivors (Jefford et al, 2011; Blaauwbroek et al, 2012; Spain et al, 2012). This must be considered when SCPs are being developed and implemented. It is likely that there are some survivors (possibly informationseeking' survivors) more suited to SCP use than others. It also highlights the need for flexibility and survivor input in determining the appropriateness and the content of an SCP.

A 2011 study evaluating the uptake and quality of treatment summaries and SCPs in 13 LiveStrong Centers of Excellence in Cancer Survivorship Network showed relatively poor adherence to IOM recommendations even in dedicated cancer institutes and their affiliated community-based treatment centres (Stricker et al, 2011). Less than half of IOM content recommendations for treatment summaries were met (mean 46\%) and less than twothirds of the recommendations for SCPs were met (mean 59\%). This suggests that there are significant barriers to the implementation of SCPs even when there is extremely strong commitment to the concept (Stricker et al, 2011). Barriers to quality survivorship care were hypothesised to include reimbursement issues, limited institutional resources including personnel, time and information/ communications systems (Stricker et al, 2011).

The current review has also highlighted resource issues (particularly time) (Grunfeld et al, 1999b; Jefford et al, 2011; Spain et al, 2012; Brothers et al, 2013). It was estimated in these studies that the development of an SCP takes at least $1 \mathrm{~h}$ (and up to $4 \mathrm{~h}$ ) regardless of whether it is developed by a doctor, a nurse or a research assistant (Grunfeld et al, 1999b; Jefford et al, 2011; Spain et al, 2012; Brothers et al, 2013). Current health-care funding models do not allow for remuneration for this considerable time. The studies in this review suggest that outcomes following delivery of the SCP by nurses (Grunfeld et al, 2011; Jefford et al, 2011; Hershman et al, 2013) and primary-care physicians (Grunfeld et al, 1996, 2006, 2011; Blaauwbroek et al, 2012) (rather than specialist oncologists), and by mail (Grunfeld et al, 1996, 2006; Oeffinger et al, 2010) or on-line(Blaauwbroek et al, 2012) (rather than in a face-to-face consultation) are similar. This means that it is possible to reduce the burden of SCP development and implementation by oncologists (a scarce resource in many nations) if there are other available and trained health professionals to share the workload.

There is great heterogeneity in the content of SCPs. Assessment of content of care plans, with reference to the IOM recommendations, is an area for further research. This would be aided by a recently published 'score card' for SCP content evaluation (Palmer et al, 2014).
At present, there exists a lack of long-term outcome data about the impact of SCPs. It is unknown whether there may be significant benefits later in the survivorship phase of care and it is unknown whether SCPs will change long-term oncological outcomes (recurrence and survival). None of the studies used has an impact on recurrence and/or survival as an aim or an outcome, as SCPs have been developed primarily as a tool to improve psychosocial and care coordination (rather than oncological) outcomes.

This study has several limitations. There is a small body of extremely heterogeneous literature on which to base conclusions and few randomised trials. This has been noted in previous discussions about interpretation of the evidence (Parry et al, 2013). The populations represented in the studies have survivors of different tumour types at different stages of survivorship represented. A number of different models of care have been presented, including different SCP templates, formats and methods of delivery. Different outcomes have been evaluated using different measurement tools and it is unclear which tools are most appropriate. The 'ceiling effect' is an additional challenge; for example, in these studies, survivors reported high levels of satisfaction with care before an SCP was introduced, making it difficult to detect an improvement if it existed (Grunfeld et al, 1996, 2011; Hershman et al, 2013). However, given the diverse needs of cancer survivors and the large spectrum of health environments in which survivors are treated, this heterogeneity also reflects the necessity for survivorship care planning to be adapted to local needs and resources. Reviewing these varied models will aid this process. This would be enhanced by consistency in the approach to planning trials (distinguishing the physical SCP document from the context of its delivery/implementation), consistency in measurement tools and consistency in the description of results (Parry et al, 2013).

\section{CONCLUSION}

This study has identified and evaluated 10 studies reporting outcomes after implementation of SCPs for cancer survivors. The emerging evidence has shown few measureable benefits to support the use of SCPs (i.e., making survivors more aware of who the clinician responsible for their care is, and possibly reducing unmet needs of some survivors). High levels of survivor satisfaction with SCPs was reported and self-reported levels of understanding were very high. Suggestion of potential harm was found, with some (nonrandomised) studies reporting an increase in cancer-related distress. Significant barriers to the implementation of SCPs were identified, including the intense resources required. Further studies of innovative SCP models, evaluating a range of outcomes in various survivor populations and using different outcome measures are required. The long-term effect of SCPs on psychosocial, oncological and resource outcomes should be evaluated. It is unlikely that one model will suit all survivors, cancer centres or tumour types (e.g., younger patients may prefer electronic care plans, and the content may need to focus more on managing endocrine symptoms when treatment-induced premature menopause occurs). Research addressing these variables in a consistent manner is needed.

\section{ACKNOWLEDGEMENTS}

This study was supported in part by The Friends of The Mater Foundation, North Sydney, Australia.

\section{REFERENCES}

Agarwal R, Aggarwal AN, Gupta D (2013) Efficacy and safety of conventional transbronchial needle aspiration in sarcoidosis: a systematic review and meta-analysis. Respir Care 58(4): 683-693. 
American Society of Clinical Oncology \& Cancer.Net (2013) ASCO Cancer Treatment Summaries. Available at http://www.cancer.net/survivorship/ follow-care-after-cancer-treatment/asco-cancer-treatment-summaries. Accessed June 2014.

Blaauwbroek R, Barf HA, Groenier KH, Kremer LC, van der Meer K, Tissing WJE, Postma A (2012) Family doctor-driven follow-up for adult childhood cancer survivors supported by a web-based survivor care plan. J Cancer Surviv 6(2): 163-171.

Blinder VS, Norris VW, Peacock NW, Griggs JJ, Harrington DP, Moore A, Theriault RL, Partridge AH (2013) Patient perspectives on breast cancer treatment plan and summary documents in community oncology care. Cancer 119(1): 164-172.

Brennan ME, Butow P, Marven M, Spillane AJ, Boyle FM (2011) Survivorship care after breast cancer treatment-experiences and preferences of Australian women. Breast 20: 271-277.

Brennan ME, Butow P, Spillane AJ, Boyle FM (2010) Survivorship care after breast cancer: Follow-up practices of Australian health professionals and attitudes to a survivorship care plan. Asia Pac J Clin Oncol 6(2): 116-125.

Brothers BM, Easley A, Salani R, Andersen BL (2013) Do survivorship care plans impact patients' evaluations of care? A randomized evaluation with gynecologic oncology patients. Gynecol Oncol 129(3): 554-558.

Cox K, Wilson E, Heath L, Collier J, Jones L, Johnston I, Cox K, Wilson E, Heath L, Collier J, Jones L, Johnston I (2006) Preferences for follow-up after treatment for lung cancer: assessing the nurse-led option. Cancer Nurs 29(3): 176-187.

de Bock GH, Bonnema J, Zwaan RE, van de Velde CJH, Kievit J, Stiggelbout AM (2004) Patient's needs and preferences in routine follow-up after treatment for breast cancer. Br J Cancer 90: 1144-1150.

Erikson C, Salsberg E, Forte G, Bruinooge S, Goldstein M (2007) Future supply and demand for oncologists: challenges to assuring access to oncology services. J Oncol Pract 3(2): 79-86.

Ganz PA, Hahn EE (2008) Implementing a survivorship care plan for patients with breast cancer. J Clin Oncol 26(5): 759-767.

Greenfield DM, Absolom K, Eiser C, Walters SJ, Michel G, Hancock BW, Snowden JA, Coleman RE (2009) Follow-up care for cancer survivors: the views of clinicians. Br J Cancer 101(4): 568-574.

Grunfeld E, Fitzpatrick R, Mant D, Yudkin P, Adewuyi-Dalton R, Stewart J, Cole D, Vessey M (1999a) Comparison of breast cancer patient satisfaction with follow-up in primary care versus specialist care: results from a randomized controlled trial. Br J Gen Pract 49(446): 705-710.

Grunfeld E, Gray A, Mant D, Yudkin P, Adewuyi-Dalton R, Coyle D, Cole D, Stewart J, Fitzpatrick R, Vessey M (1999b) Follow-up of breast cancer in primary care vs specialist care: results of an economic evaluation. Br J Cancer 79(7-8): 1227-1233.

Grunfeld E, Julian JA, Pond G, Maunsell E, Coyle D, Folkes A, Joy AA, Provencher L, Rayson D, Rheaume DE, Porter GA, Paszat LF, Pritchard KI, Robidoux A, Smith S, Sussman J, Dent S, Sisler J, Wiernikowski J, Levine MN (2011) Evaluating survivorship care plans: results of a randomized, clinical trial of patients with breast cancer. J Clin Oncol 29(36): 4755-4762.

Grunfeld E, Levine MN, Julian JA, Coyle D, Szechtman B, Mirsky D, Verma S, Dent S, Sawka C, Pritchard KI, Ginsburg D, Wood M, Whelan T (2006) A randomized controlled trial (RCT) of routine follow-up for early stage breast cancer: A comparison of primary care versus specialist care. $J$ Clin Oncol 24(6): 848-855.

Grunfeld E, Mant D, Yudkin P, Adewuyi-Dalton R, Cole D, Stewart J, Fitzpatrick R, Vessey M (1996) Routine follow up of breast cancer in primary care: randomised trial. BMJ 313(7058): 665-669.

Hershman DL, Greenlee H, Awad D, Kalinsky K, Maurer M, Kranwinkel G, Brafman L, Jayasena R, Tsai W, Neugut AI, Crew KD (2013) Randomized controlled trial of a clinic-based survivorship intervention following adjuvant therapy in breast cancer survivors. Breast Cancer Res Treat 138: 795-806.

Hewitt M, Greenfield S, Stovall E (eds) (2006) From Cancer Patient to Cancer Survivor: Lost in Transition. National Academy of Sciences: Washington, DC.

Hewitt ME, Bamundo A, Day R, Harvey C (2007) Perspectives on post- treatment cancer care: qualitative research with survivors, nurses, and physicians. J Clin Oncol 25: 2270-2273.

Jefford M, Lotfi-Jam K, Baravelli C, Grogan S, Rogers M, Krishnasamy M, Pezaro C, Milne D, Aranda S, King D, Shaw B, Schofield P (2011) Development and pilot testing of a nurse-led posttreatment support package for bowel cancer survivors. Cancer Nurs 34(3): E1-10.
Kantsiper M, McDonald EL, Geller G, Shockney L, Snyder C, Wolff AC (2009) Transitioning to breast cancer survivorship: perspectives of patients, cancer specialists, and primary care providers. J Gen Intern Med 24(Suppl 2): S459-S466.

Khatcheressian JL, Hurley P, Bantung E, Esserman LJ, Grunfeld E, Halberg F, Hantel A, Henry NL, Muss HB, Smith TJ, Vogel VG, Wolff AC, Somerfield MR, Davidson NE (2013) Breast cancer follow-up and management after primary treatment: american society of clinical oncology clinical practice guideline update. J Clin Oncol 31(7): 961-965.

Khatcheressian JL, Wolff AC, Smith TJ, Grunfeld E, Muss HB, Vogel VG, Halberg F, Somerfield MR, Davidson NE (2006) American Society of Clinical Oncology 2006 update of the breast cancer follow-up and management guidelines in the adjuvant setting. J Clin Oncol 24(31): 5091-5097.

Kmet LM, Lee RC, Cook LS (2004) Standard quality assessment criteria for evaluating primary research papers from a variety of fields. HTA Initiative \#13: 1-22.

Laidsaar-Powell RC, Butow PN, Bu S, Charles C, Gafni A, Lam WW, Jansen J, McCaffery KJ, Shepherd HL, Tattersall MH, Juraskova I (2013) Physicianpatient-companion communication and decision-making: a systematic review of triadic medical consultations. Patient Educ Couns 91(1): 3-13.

Liberati A, Altman DG, Tetzlaff J, Mulrow C, Gotzsche PC, Ioannidis JPA, Clarke M, Devereaux PJ, Kleijnen J, Moher D (2009) The PRISMA statement for reporting systematic reviews and meta-analyses of studies that evaluate health care interventions: explanation and elaboration. PLoS Med 6(7): e1000100.

Marbach TJ, Griffle J (2011) Patient preferences concerning treatment plans, survivorship care plans, education, and support services. Oncol Nurs Forum 38(3): 335-342.

Medical Oncology Group of Australia (2009) The Australian Medical Oncologist Workforce Study 2009. Available at https://www.moga.org.au/ sites/default/files/The_Australian_Medical_Oncologist_Workforce_ Study_2009.pdf. Accessed June 2014.

National Breast and Ovarian Cancer Centre (NBOCC) (2010) Recommendations for Follow-Up of Women with Early Breast Cancer. National Breast and Ovarian Cancer Centre: Surry Hills.

Oeffinger KC, Hudson MM, Mertens AC, Smith SM, Mitby PA, Eshelman-Kent DA, Ford JS, Jones JK, Kamani S, Robison LL (2010) Increasing rates of breast cancer and cardiac surveillance among high-risk survivors of childhood Hodgkin lymphoma following a mailed, one-page survivorship care plan. Pediatr Blood Cancer 56(5): 818-824.

Palmer SC, Jacobs LA, DeMichele A, Risendal B, Jones AF, Stricker CT (2014) Metrics to evaluate treatment summaries and survivorship care plans: a scorecard. Support Care Cancer 22(6): 1475-1483.

Parry C, Kent EE, Forsythe LP, Alfano CM, Rowland JH (2013) Can't see the forest for the care plan: a call to revisit the context of care planning. J Clin Oncol 31(21): 2651-2653.

Smith SL, Singh-Carlson S, Downie L, Payeur N, Wal ES (2011) Survivors of breast cancer: patient perspectives on survivorship care planning. J Cancer Surviv 5(4): 337-344.

Spain PD, Oeffinger KC, Candela J, McCabe M, Ma X, Tonorezos ES (2012) Response to a treatment summary and care plan among adult survivors of pediatric and young adult cancer. J Oncol Prac 8(3): 196-201.

St Jacques S, Grenier S, Charland M, Forest JC, Rousseau F, Légaré F (2008) Decisional needs assessment regarding Down syndrome prenatal testing: a systematic review of the perceptions of women, their partners and health professionals. Prenat Diagn 28(13): 1183-1203.

Stricker CT, Jacobs LA, Risendal B, Jones A, Panzer S, Ganz PA, Syrjala KL, McCabe MS, Baker KS, Miller K, Casillas J, Rosenstein DL, Campbell M, Palmer SC (2011) Survivorship care planning after the Institute of Medicine recommendations: how are we faring? J Cancer Surviv 5(4): 358-370.

Wassenaar A, Schouten J, Schoonhoven L (2014) Factors promoting intensive care patients' perceptions of feeling safe: A systematic review. Int J Nurs Stud 51(2): 261-273.

This work is published under the standard license to publish agreement. After 12 months the work will become freely available and the license terms will switch to a Creative Commons AttributionNonCommercial-Share Alike 3.0 Unported License. 